\title{
IJARA AS AN INNOVATIVE PRODUCT IN AGRICULTURAL FINANCING
}

\author{
Aijamal K. Kantoroeva*, Nurzat K. Toktomamatova \\ International University named after Kantoro Sharipovich Toktomamatov, Jalal-Abad, Kyrgyz Republic.
}

\section{ART ICLE INF O}

\section{Article History}

Received: April 21, 2021

Revised: July 1, 2021

Accepted: July 30, 2021

\section{Keywords}

Interest rate

Islamic principles of lending

Commercial bank

leasing company

Credit organization

\section{A B S T R A C T}

The relevance of the study is due to the necessity to solve the problems of agricultural lending in the Kyrgyz Republic. The problems of financing and lending to agriculture are still urgent in the Kyrgyz Republic, therefore, specific financial instruments of Islamic banking, which are highly appreciated in the practise of other countries, are well suited for project financing, work in conditions of high uncertainty characteristic of agriculture in the Kyrgyz Republic. The purpose of the study was to identify alternative loan products for agricultural economic entities based on Islamic principles of financing in the Kyrgyz Republic. Research objectives: to provide brief information on the current state in the field of agricultural lending; give brief information on the development of Islamic principles of lending in the Kyrgyz Republic; define the concept and classification of Islamic banking instruments in agriculture; define the financial instrument "Ijara" and identify its advantages. Research methods: methods of the empirical level (studying of literature and other sources of information, observation, comparison), methods of the theoretical level (study and generalisation, analysis and synthesis). In the process of writing this article, Islamic banking instruments have been reviewed and classified. The concept of Ijara contract was considered, new modern technologies in the field of Islamic banking were investigated. The main distinctive principles of Islamic banking from the Western model of financial leasing were analysed. The credit history of agriculture and forestry of the Kyrgyz Republic was analysed.

Corresponding Author: Aijamal K. Kantoroeva

Email: kantoroeva5902@tanu.pro

(C) The Author(s) 2021.

\section{INTRODUCTION}

In the Kyrgyz Republic, the history of the development of financing based on Islamic principles dates back to the summer of 2005, when at the level of the head of the country the problem of the lack of effective lending to the population in the long term was raised and a decision was made to search and implement the best experience in the lending system. The solution to this problem was the introduction of financing based on Islamic principles, along with the already existing traditional financing instruments, Islamic banking began to be used. The last decade has shown that the concept of "Islamic bank" has become entrenched in the lexicon of financiers in most of the developed countries of the world. This financial institution, which operates in Muslim countries, is gradually entering the global financial market and being introduced into traditional financial systems. Consequently, the study of Islamic financial institutions is a popular topic in the world economic literature and is also of practical interest for economic agents in Kyrgyzstan.

To date, the National Bank of Kyrgyzstan has formed all the necessary legal and regulatory framework for conducting activities based on Islamic financing criteria 
(Gambeeva and Medvedeva, 2018). The problems of financing and lending to agriculture are still urgent in the Kyrgyz Republic, therefore, specific financial instruments of Islamic banking, which are highly appreciated in the practise of other countries, are well suited for project financing, working in conditions of high uncertainty typical for agriculture in the Kyrgyz Republic (Sigaev, 2014). The purpose of the study was to identify alternative loan products for agricultural economic entities based on Islamic principles of financing in the Kyrgyz Republic. Research objectives: to provide brief information on the current state in the field of agricultural lending; give brief information on the development of Islamic principles of lending in the Kyrgyz Republic; define the concept and classification of Islamic banking instruments in agriculture; define the financial instrument "Ijara" and identify its advantages.

\section{MATERIALS AND METODS}

In the Kyrgyz Republic, Islamic banking is handled by CJSC "EcoIslamicBank", which is the only large financial institution in the CIS that operates according to Islamic principles of financing (IPF). "EcoIslamicBank" has a license from the National Bank of the Kyrgyz Republic for the right to carry out transactions on Islamic principles of financing in accordance with the regulation "On the implementation of Islamic principles of financing in the Kyrgyz Republic within the framework of a pilot project" (National Bank of the Kyrgyz Republic, 2018). "EcoIslamicBank" is the first bank in Kyrgyzstan, which began to provide a full range of financial services, which were based on the principles of Sharia. To date, a wide network of 110 subdivisions has been created throughout the republic (Kovalenko et al., 2019;
Zatsarinnyi et al., 2018). The client base of the studied bank is more than 100000 clients, the bank offers a variety of services for Islamic deposits, financing, servicing bank cards, halal transfers and much more (Voronkova et al., 2019). Islamic finance includes a wide range of financial products and services. Most Islamic finance products have some similarities with classical financial products, this similarity is due to their basic purpose (Azmat et al., 2020). The basic purpose of Islamic finance products is to seek to act in the direction of investment growth on the part of entities that own capital, as well as entities that need it. Four main principles govern Islamic finance (Mohd Noor et al., 2018). The first is that investments cannot affect businesses that produce or distribute alcohol, pork products, gambling, weapons, or pornography (Sanghera and Satybaldieva, 2020). The second principle is that investments cannot include payment or receipt of interest. According to the third principle, investments cannot involve speculation or transactions with a degree of uncertainty. The fourth principle regulates the issue of risk sharing, according to this principle, the risks of any transaction must be shared at least between two parties (Bondarenko et al., 2019; Zaman, 2019).

\section{RESULTS AND DISCUSSION}

\section{Analysis of the credit history of agriculture and forestry of the Kyrgyz Republic}

Today in the republic the most vulnerable layer of bank clients is representatives of agriculture, a high percentage of force majeure circumstances affecting activities, a long turnaround time (especially in animal husbandry), etc. At the end of 2018, 440055 economic entities operated in the republic in the field of agriculture, forestry, economy and fisheries (Figure 1).

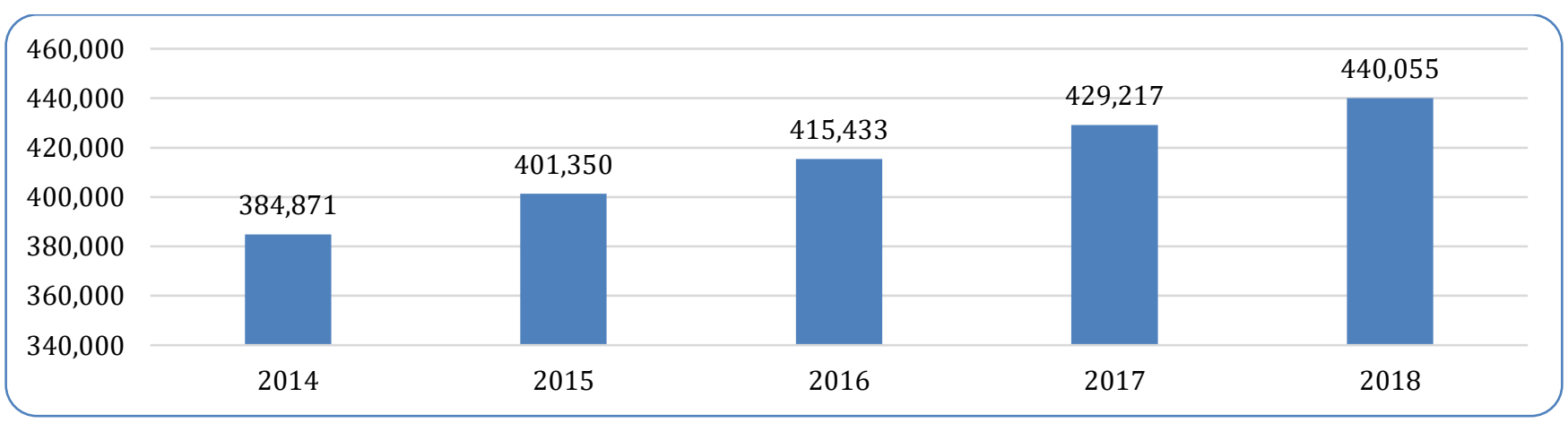

Figure 1. The number of operating economic entities in agriculture, forestry, economy and fisheries, units (National Statistical Committee, 2020). 
Figure 1 shows that the number of economic entities in the field of agriculture, forestry and fisheries tends to grow, if to compare 2018 and the base year 2014, then the increase occurred by 14.3 percent or 55184 units, compared to the previous year, an increase of 2.5 percent or by 10838 units.

This trend is associated with the fact that a favourable policy in the field of state support for the conditions of agricultural production is developing, the needs of domestic consumers are growing, in particular, for meat and fish, which give preference to products of domestic producers (Figure 2). But with all this situation, the share of agriculture in the Kyrgyz Republic has a tendency to decrease, so back in 2014 it was $14.7 \%$, and in $2018-11.7 \%$, or decreased in $3.0 \%$. (Figure 2). The downward trend is explained by the upward trend in the share of gross value added in the GDP of industrial entities.

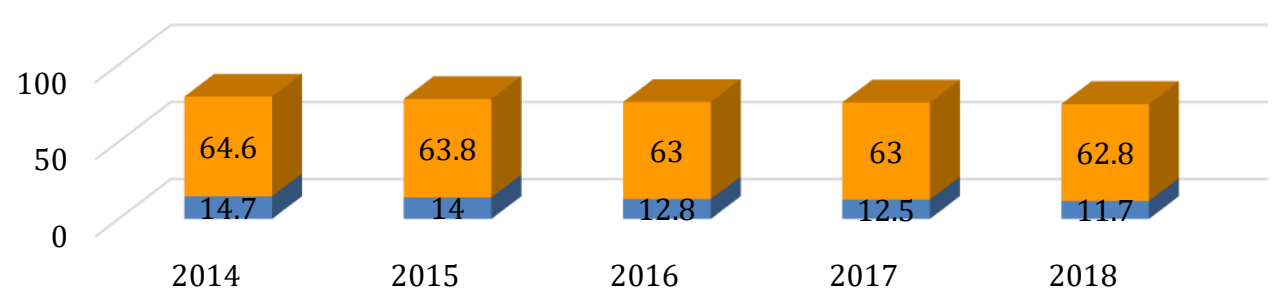

The share of operating economic entities of agriculture, forestry, and fisheries in general volume of the economic entities, $\%$

The share of agriculture in GDP, \%

Figure 2. The share of gross value added in the GDP of agricultural entities, in percent (National Statistical Committee, 2020).

There is a slight positive trend in the field of lending by commercial banks and credit institutions to agriculture, forestry, fishing, for example, the volume of loans issued to this industry in 2018 amounted to 26030.9 million soms, which compared to the base year 2014 increased by 18.4 percent or 4044.2 million, and in comparison, with the previous 2017, the increase in the volume of loans amounted to 13.2 percent or 3039.0 million soms. The volume of transactions on financial leasing (agricultural machinery, machinery and equipment) for agriculture, forestry, fishing, carried out by credit institutions and leasing companies, also shows a slight growth trend, for example, in 2018 these volumes reached 596.1 million soms, which is since 2014 , it is higher by 128.1 percent or by 334.8 million soms. If we take an average, then in 2018 the volume of loans per 1 unit of economic entities in agriculture, forestry, economy and fishing amounted to 59153.7 soms, and for financial leasing - 1293.2 soms (Figure 3 ). These figures are very small for this industry. Such small volumes of lending are also affected by high interest rates (Figure 4).

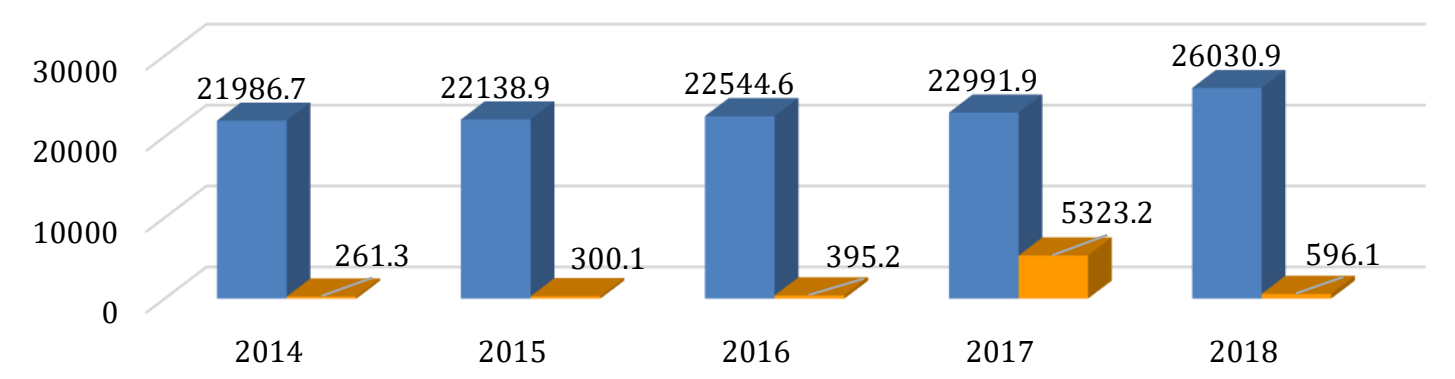

Loans to agriculture, forestry, fisheries $\quad$ Financial leasing (agriculture equipment, mashines, mechanisms)

Figure 3. The volume of loans and financial leasing to agriculture, forestry, fisheries issued by commercial banks and leasing companies, million soms (National Statistical Committee, 2020). 


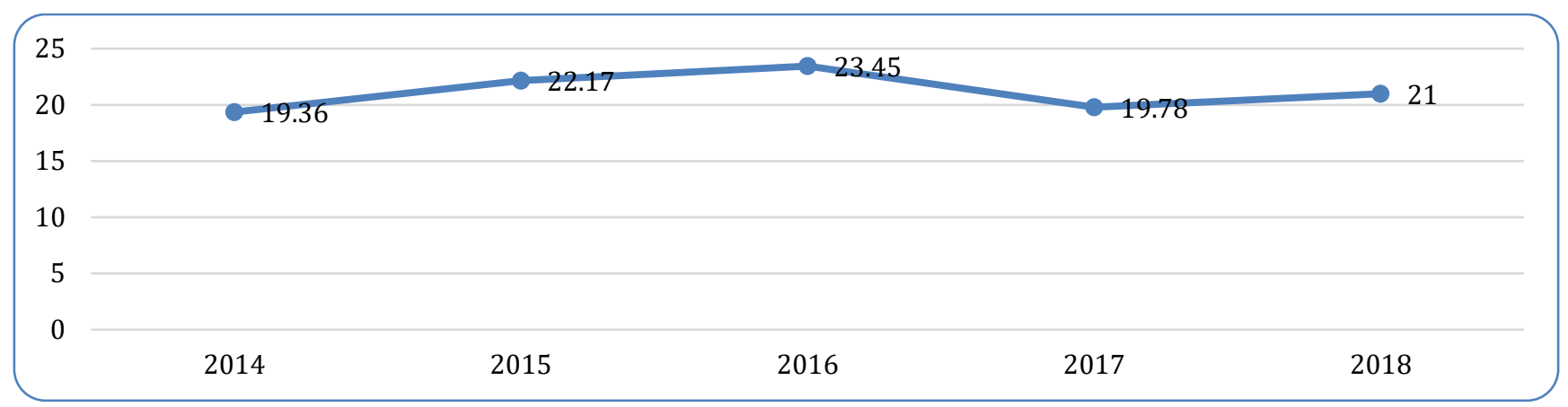

Figure 4. The weighted average interest rate of commercial banks on loans issued in the national currency to agricultural entities from 1 to 3 years (National Bank of the Kyrgyz Republic, 2018).

In general, such rates from 19 percent to 24 percent for representatives of agriculture are high, as mentioned above, representatives of agriculture are subject to more frequent natural and epidemiological risks and have a long turnaround time. A great difficulty in obtaining loans is a very long and high assessment of the business projects of borrowers and their solvency, while sufficient collateral is required, the term for considering documents for commercial lending takes a lot of time, which is unacceptable for agricultural entities (Brodskiy et al., 2019). This situation in the field of lending, as well as the intensification of crisis events in the modern world, should push towards the development of agriculture by providing access to other types of financing for Kyrgyz agricultural producers (Rudnyckyj, 2017). In this situation, more than ever, Islamic principles of lending should come to the rescue. In the post-Soviet area, a system of financial relations focused on Islamic financing criteria appeared already at the end of the 80 s of the 20th century, a specific characteristic of such financing is that it does not imply interest (Naguib,
2019). "Islamic banking is based on Sharia - a set of rules and laws concerning economic management, social, political and cultural aspects of the Islamic society" (Huseynov and Khusainov, 2013).

\section{Modern technologies in the field of Islamic banking} The concept of Islamic banking appeared in the early $80 \mathrm{~s}$ of the 20th century and in recent years has begun to appear in the lexicon of financiers in all countries of the world. This financial institution is gaining ground and today is an important component of the global financial system. This trend is due to the number of citizens in different countries who profess Islam and refuse to use the services of traditional banks (Haiduchok et al., 2020; Sivash et al., 2019). The abandonment of traditional banks is popular among Muslims in the United States, Great Britain and other European countries. This has become the reason for the actualisation of the study of Islamic banking throughout the world. Table 1 provides information on the main differences between Islamic banks and traditional ones.

Table 1. The main differences between Islamic banks and traditional.

\begin{tabular}{lll}
\hline Characteristics & Traditional bank & Islamic bank \\
\hline $\begin{array}{l}\text { Guaranteed payments on demand deposits } \\
\text { Guaranteed payments on investment } \\
\text { deposits }\end{array}$ & Yes & Yes \\
\hline Interest rate on deposits & $\begin{array}{l}\text { Determined and } \\
\text { guaranteed }\end{array}$ & $\begin{array}{l}\text { Is not determined by the profitability of a } \\
\text { bank, return on investment }\end{array}$ \\
\hline $\begin{array}{l}\text { The mechanism for determining the interest } \\
\text { rate on deposits }\end{array}$ & $\begin{array}{l}\text { Does not depend on } \\
\text { profitability of a bank }\end{array}$ & $\begin{array}{l}\text { Determined by the profitability of the } \\
\text { bank, return on investment }\end{array}$ \\
\hline $\begin{array}{l}\text { Participation of depositors in a profit and } \\
\text { loss of a bank }\end{array}$ & Almost no & Yes \\
\hline $\begin{array}{l}\text { The right of a bank to make a decision on } \\
\text { granting a loan depending on a collateral }\end{array}$ & Always yes & $\begin{array}{l}\text { With the participation of depositors in the } \\
\text { profits and losses of an Islamic bank, it } \\
\text { most often does not have the right to } \\
\text { discriminate against customers } \\
\text { depending on the collateral they have. }\end{array}$ \\
\hline
\end{tabular}


The activities of the Islamic Financial Centre OJSC "Bakai Bank" can be referred to the number of innovative approaches in the field of lending based on Islamic principles (Ahmad Lone and Ahmad, 2017; Alharbi, 2016). This bank opened in 2018 and became the first commercial bank in the CIS to receive a regulatory license to launch a full range of Islamic banking services. With the launch of the Islamic Financial Centre, the citizens of Kyrgyzstan have an opportunity to receive funds for the purchase of small household appliances, a car, an apartment, and even for business Alharbi (Bekmansurov et al., 2019; Udalova et al., 2019). At the same time, the Centre's specialists are personally involved in the development of business projects, assessing the risks of possible losses and strategies to increase the income of their partners.

The financing system, built on the principles of Islam, should solve such priority development tasks as:

- for all subjects of the agricultural industry, the terms for deciding on the provision of project financing will be reduced;

- due to excessive exposure to the significant impact of agro-climatic risks, more flexible financing conditions can be provided, which are more consistent with the specifics of the agricultural business;

- for small agribusiness, the system of access to bank and leasing financing will continue to be simplified;

- on agricultural loans, bank interest rates will decrease, the range of state support will expand.

Today the volume of "Islamic financial transactions" in the world is estimated at USD 2.3 trillion Ahmad and Ahmad (National Statistical Committee of the Kyrgyz Republic, 2020). In 2020, it is expected to rise to USD 2.8 trillion. More than 2500 Islamic financial institutions operate in 102 countries around the world (Angioloni et al., 2017). The overwhelming part of the population of the Islamic world is rural residents, therefore, the efficiency and sustainability of agricultural production is a basic requirement of social stability in these countries, for example, a significant share of agricultural producers in the Middle East and North Africa are small and medium-sized farms that do not have a sufficient collateral base, and in the Kyrgyz Republic, out of 440055 agricultural producers, 332909 are small and medium-sized farms, which is $75.6 \%$ of all economic entities (National Statistical Committee of the Kyrgyz
Republic, 2020).

The main five principles of Islamic finance are: prohibition of interest rate, risk sharing, money is potential capital, the principle of prohibition of speculative behaviour, the principle of compliance with a contract. The principle of prohibiting the interest rate is to prohibit a predetermined rate, which depends on the terms and size of a loan. This principle is based on the Muslim religion, which prohibits the use of interest for profit. Islamic laws explain that enrichment by charging interest does not contribute to the creation of a product and does not increase the level of well-being of citizens (Makushkin, 2019; Rudenko and Hochradel, 2017). The second principle of Islamic finance is the sharing of risk between a bank and a borrower. According to this principle, the bank becomes an investor for the borrower's project. The third principle of Islamic banking is that money is potential capital. This means that they become real capital in the process of investing in production activities. The principles of Islamic finance prohibit speculative behaviour, which implies a ban on gambling and working with derivative financial instruments, since such transactions are characterised by significant risk. The last principle consists in the mandatory execution of agreements between a bank and a borrower, which greatly reduces the risks for all participants in the process (Bakhov, 2014; Mishchenko et al., 2019).

The financial technologies used in these countries "Islamic banking" - successfully solve the difficult problem of ensuring the availability of financing for small and medium agricultural producers in the context of risky farming (Botoeva, 2018). This experience can find wide application in the Kyrgyz Republic. Exploring the tools of Islamic banking in agriculture, the following classification can be derived (Figure 5).

In Islamic banking, the analogue of financial leasing is the Ijara contract, which has a variation called Ijara Muntahiyya Bittamlik (Hoggarth, 2016). In his book "An Introduction to Islamic Finance" Mufti Muhammad Taki Usmani gives the following definition of Ijara: "Ijara is a type of investment activity for the special acquisition of equipment or other property by the lessee and its provision to the tenant for property lease (lease) for temporary possession and use for an agreed period for a fee" (Usmani, 2001). 


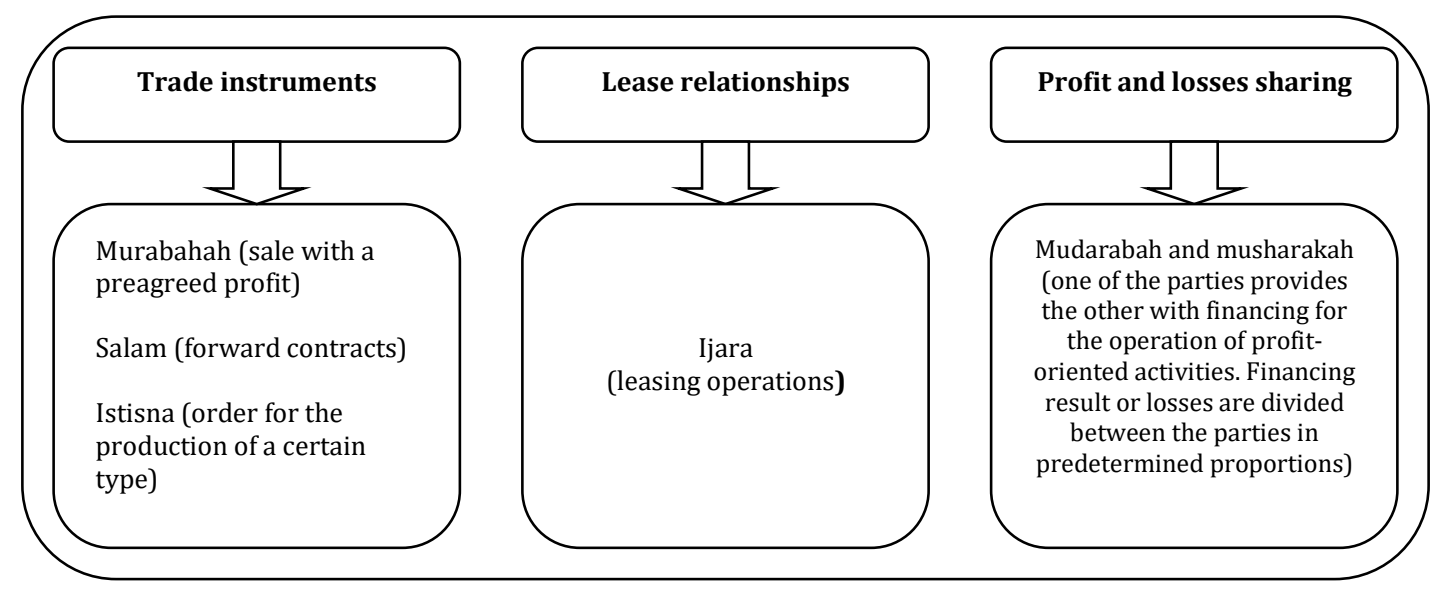

Figure 5. Islamic banking tools in agriculture.

The Civil Code of the Kyrgyz Republic in article 738 (Civil Code of the Kyrgyz Republic, 1996) defines an Ijara agreement, which indicates that this is an agreement for the special acquisition by the lessor of equipment or other property in ownership and its provision to the lessee for property lease for temporary possession and use for an agreed period, on a paid basis, with or without the right of redemption, in accordance with the concluded Ijara agreement (without redemption) or the Ijara Muntahiyya Bittamlik agreement (with redemption). The basis of an Ijara transaction is the provision for use (rent, leasing) of a specific asset to the client Jessop (Basiurkina et al., 2020; Jessop, 2015). The bank's income from this operation is lease payments within the agreed period of use (rent, leasing).

The main difference from the Western model of financial leasing is as follows: the absence of conditions for the sale of an asset in an Ijara agreement; the physical risks of an asset are borne by a bank; sale of an asset after the end of the lease period as part of a sale (iktin) transaction; the possibility of free transfer of an asset with a minimum residual value. The introduction of innovative technologies, namely Ijara agreements, into the banking system of the Kyrgyz Republic includes a number of positive and negative aspects (Dotsenko et al., 2017; Zhigir, 2020). The positive aspects of the introduction of Islamic banking in the Kyrgyz Republic are: the ability to invest in real projects and the economy, the Islamic banking model is recognised as less risky, and also more socially oriented (Ezdina, 2017; Ivanov et al., 2015). With the introduction of Islamic banking and modern technologies, citizens of the Kyrgyz Republic will be given the opportunity to conclude Ijara agreements, which are less risky than leasing agreements in traditional banks. However, the Islamic banking system also has negative aspects. One of the key negative aspects for citizens of the Kyrgyz Republic will be limited investment opportunities on the part of Islamic banks. Therefore, Islamic banking can provide the citizens of the Kyrgyz Republic with new opportunities and provide proper investment and financing for the agricultural sector.

\section{CONCLUSIONS}

The differences between Islamic banking and traditional financial technologies are based on the cultural characteristics of Islam, which prohibits, including usury and excessive uncertainty in transactions. With regard to the banking and stock market, this means a ban on the provision of loans at a guaranteed interest rate, as well as on futures contracts. In the process of writing this article, the Civil Code of the Kyrgyz Republic was analysed. The tools of Islamic banking in agriculture were considered and classified. The concept of Ijara contract, which is analogous to financial leasing in Islamic banking, was considered, as well as a type of Ijara contract called Ijara Muntahiyya Bittamlik. This paper explores new modern technologies in the field of Islamic banking, including the activities of the Islamic Financial Centre OJSC "Bakai Bank". This centre provided citizens with the opportunity to receive funds for the purchase of small household appliances, cars, apartments, as well as for starting and developing a business.

The main distinctive principles of Islamic banking from the Western model of financial leasing were analysed. 
This work has studied the following basic issues: the weighted average interest rate of commercial banks on loans issued in national currency to agricultural entities; the volume of loans and financial leasing to agriculture, forestry, fisheries issued by commercial banks and leasing companies; the share of gross value added in the GDP of agricultural entities. Also, the number of operating economic entities of agriculture, forestry and fishing in the territory of the Kyrgyz Republic was calculated and analysed. Analysis of the number of operating economic entities in agriculture, forestry and fisheries showed that the number of economic entities has a growing trend. However, the analysis of the share of gross value added in the GDP of agricultural entities showed that the share of agriculture in the Kyrgyz Republic tends to decrease. Also, there is a slight positive trend in the field of lending by commercial banks and credit institutions. This situation in the field of lending, as well as the intensification of crisis events in the modern world, should push the Kyrgyz Republic to develop the agricultural sector by providing access to other types of financing for Kyrgyz agricultural producers. In these conditions, specific financial instruments of Islamic banking were formed, which, as practice has shown, are very well suited for project financing, work in conditions of high uncertainty typical for agriculture.

\section{REFERENCES}

Ahmad Lone, F. and S. Ahmad. 2017. Islamic finance: more expectations and less disappointment. Investment Management and Financial Innovations, 14: 134-141.

Alharbi, A. 2016. Development of Islamic Finance in Europe and North America : Opportunities and Challenges. International Journal of Islamic Economics and Finance Studies, 2: 109-136.

Angioloni, S., Z. Kudabaev, G. C. W. Ames and M. Wetzstein. 2017. Household allocation of microfinance credit in Kyrgyzstan. PostCommunist Economies, 30: 78-98.

Azmat, S., H. Ali, K. Brown and M. Skully. 2020. Persuasion in Islamic finance. Australian Journal of Management, 46: 272-286.

Bakhov, I. S. 2014. Dialogue of cultures in multicultural education. World Applied Sciences Journal, 29: 106-109.

Basiurkina, N., I. Sysoieva, J. Ratushna, T. Kotenko, N.
Baistriuchenko and A. Sukhanova. 2020. Substantiation of the innovation and investment project using the method of real options. International Journal of Management, 11: 497510.

Bekmansurov, R. H., K. E. Kovalenko, K. M. Utkina, Y. A. Novikova and E. I. Zatsarinnaya. 2019. State support for persons with disabilities in the field of entrepreneurship. Journal of Entrepreneurship Education, 22: 1-9.

Bondarenko, S., L. Bodenchuk, O. Krynytska and I. V. Haivoronska. 2019. Modelling instruments in risk management. International Journal of Civil Engineering and Technology, 10: 1561-1568.

Botoeva, A. 2018. Islam and the Spirits of Capitalism: Competing Articulations of the Islamic Economy. Politics \& Society, 46: 235-264.

Brodskiy, A. V., V. A. Gorbachev, O. E. Karpov, V. A. Konyavsky, N. A. Kuznetsov, A. M. Raigorodskii and S. A. Trenin. 2019. Identification in Digital Economy Computer Systems. Journal of Communications Technology and Electronics, 64: 1493-1499.

Dotsenko, E., N. Ezdina, A. Prilepskaya and K. Pivnyk. 2017. Sustainable Development Strategy for Russian Mineral Resources Extracting Economy. E3S Web of Conferences, 21: 04014.

Ezdina, N. 2017. Humanity and Environment Coinfluence in the Shadow of Technological Convergence. E3S Web of Conferences, 21: 04015.

Gambeeva, Y. N. and S. N. Medvedeva. 2018. Islamic finance: features of formation and development. Russian Entrepreneurship, 19: 335-349.

Haiduchok, T., I. Sysoieva, S. Vasylishyn, A. Lysiuk, 0. Kundrya-Vysotska and A. Kostyrko. 2020. Accounting and control of settlements with counterparties under the conditions of quarantine measures. International Journal of Advanced Research in Engineering and Technology (IJARET), 11.

Hoggarth, D. 2016. The rise of Islamic finance: postcolonial market-building in central Asia and Russia. International Affairs, 92: 115-136.

Huseynov, D. K. and M. K. Khusainov. 2013. Theoretical foundations of Islamic banking. , 3: 265-69. Business in Law, 3: 265-269.

Ivanov, V. V., V. I. Mishchenko and O. K. Maliutin. 2015. International experience of inflation targeting: 
Model of success for Ukraine. Aktual'ni Problemy Ekonomiky= Actual Problems in Economics: 414.

Jessop, B. 2015. Hard cash, easy credit, fictitious capital: Critical reflections on money as a fetishised social relation. Finance and Society, 1: 20-37.

Kovalenko, K. E., E. A. Osadchy, L. V. Goloshchapova, A. O. Zekiy, V. V. Lvov, G. V. Meshkova and A. F. Bagautdinov. 2019. Models of business education in Russia and their main competitive advantages. Journal of Entrepreneurship Education, 22: 1-8.

Makushkin, S. A. 2019. Company's personnel motivation. Espacios, 40: 1-10.

Mishchenko, S., S. Naumenkova, V. Mishchenko, V. Ivanov and R. Lysenko. 2019. Growing discoordination between monetary and fiscal policies in Ukraine. Banks and Bank Systems, 14: 40-49.

Mohd Noor, N. S., A. G. Ismail and M. H. Mohd. Shafiai. 2018. Shariah Risk: Its Origin, Definition, and Application in Islamic Finance. SAGE Open, 8: 215824401877023.

National Bank of the Kyrgyz Republic. 2018. National Bank of the Kyrgyz Republic. https://www.nbkr.kg/index1.jsp?item=137\&lang $=$ RUS.

National Statistical Committee of the Kyrgyz Republic. 2020. National Statistical Committee of the Kyrgyz Republic. http://stat.kg/ru/publications/sbornikselskoe-hozyajstvo-kyrgyzskoj-respubliki/.

Rudenko, M. N. and R. Hochradel. 2017. Assessing the Impact of the Competency Level on the Success of Companies' Integration. Economy of Region: 106113.

Rudnyckyj, D. 2017. Subjects of Debt: Financial Subjectification and Collaborative Risk in Malaysian Islamic Finance. American Anthropologist, 119: 269-283.
Sanghera, B. and E. Satybaldieva. 2020. Selling debt: Interrogating the moral claims of the financial elites in Central Asia. Capital \& Class: 030981682094317.

Sigaev, E. A. 2014. Islamic leasing: concept, essence and prospects for Kazakhstan. Bulletin of the University of Turan, 3: 47-50.

Sivash, 0., D. Ushakov and M. Ermilova. 2019. Investment Process Resource Provision in the Agricultural Sector. IOP Conference Series: Earth and Environmental Science, 272: 032118.

Udalova, Z., K. Burtseva, A. Alekseev and A. Udalov. 2019. Accounting and analytical aspect of risk management of agricultural organizations. IOP Conference Series: Earth and Environmental Science, 403: 012130.

Usmani, M. M. T. 2001. An Introduction to Islamic Finance. BRILL.

Voronkova, O. Y., L. A. Iakimova, I. I. Frolova, C. I. Shafranskaya, S. G. Kamolov and N. A. Prodanova. 2019. Sustainable Development of Territories Based on the Integrated Use of Industry, Resource and Environmental Potential. International Journal of Economics and Business Administration, VII: 151-163.

Zaman, A. 2019. Islam's Gift: An Economy of Spiritual Development. American Journal of Economics and Sociology, 78: 443-491.

Zatsarinnyi, E. I., N. I. Malykh, Y. N. Severina, A. L. Gendon, A. Y. Minnullina and K. A. Malyshenko. 2018. Current Trends in the Financial Market Development. Journal of Advanced Research in Law and Economics, 8: 2629.

Zhigir, A. A. 2020. Calculation of the economic effect of environmental measures. IOP Conference Series: Earth and Environmental Science, 421: 072002.

Publisher's note: EScience Press remains neutral with regard to jurisdictional claims in published maps and institutional affiliations.

Open Access This article is licensed under a Creative Commons Attribution 4.0 International License, which permits use, sharing, adaptation, distribution and reproduction in any medium or format, as long as you give appropriate credit to the original author(s) and the source, provide a link to the Creative Commons license and indicate if changes were made. The images or other third-party material in this article are included in the article's Creative Commons license, unless indicated otherwise in a credit line to the material. If material is not included in the article's Creative Commons license and your intended use is not permitted by statutory regulation or exceeds the permitted use, you will need to obtain permission directly from the copyright holder. To view a copy of this license, visit http://creativecommons.org/licenses/by/4.0/. 